Supporting information for

\title{
Visual Biopsy by Hydrogen Peroxide-induced Signal Amplification
}

Wenjie Zhao, ${ }^{\dagger}$ Sheng Yang, ${ }^{\ddagger}$ Jinfeng Yang, ${ }^{\S}$ Jishan Li,${ }^{\dagger}$ Jing Zheng, ${ }^{\dagger}$ Zhihe Qing, ${ }^{\star}$ and Ronghua Yang ${ }^{\dagger,+*}$

${ }^{\dagger}$ State Key Laboratory of Chemo/Biosensing and Chemometrics, College of Chemistry and Chemical Engineering, and Collaborative Innovation Center for Chemistry and Molecular Medicine, Hunan University, Changsha, 410082, P. R. China; ${ }^{\star}$ School of Chemistry and Biological Engineering, Changsha University of Science and Technology, Changsha, 410004, P. R. China. ${ }^{\S}$ The Affiliated Cancer Hospital of Xiangya School of Medicine, Central South University, Changsha, 410011, P. R. China.

*To whom correspondence should be addressed:

E-mail: Yangrh@pku.edu.cn

Fax: +86-731-8882 2523 


\section{Contents}

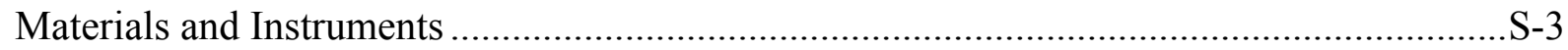

The detailed synthesis and structural characterizations of $(1)-(6)$....................................... -4

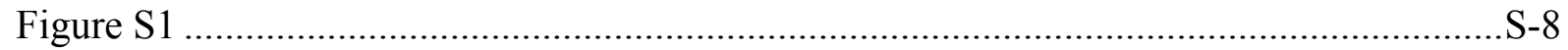

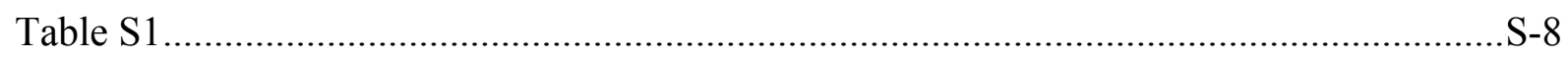

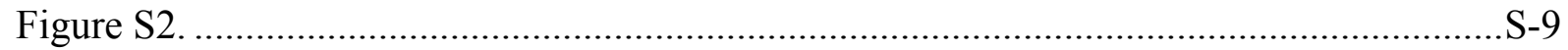

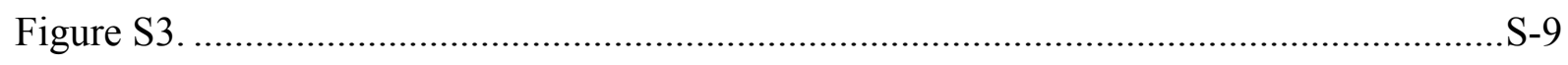

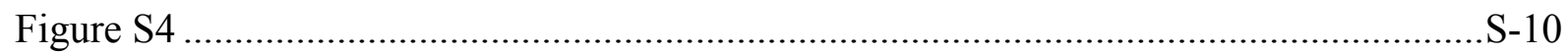

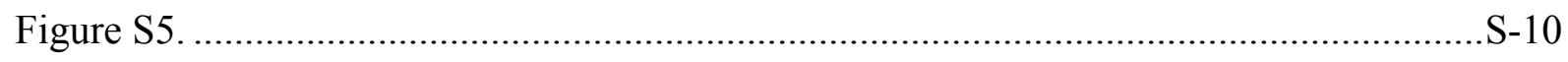

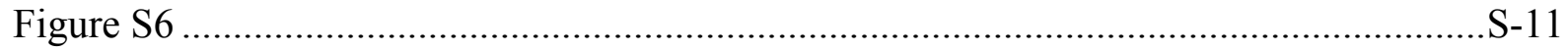

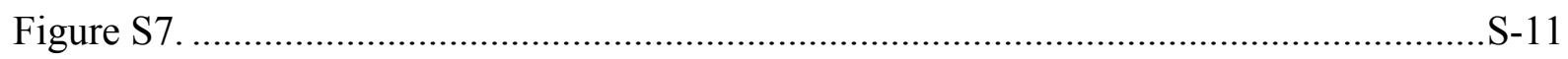

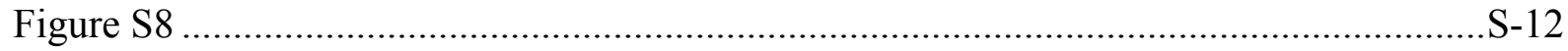

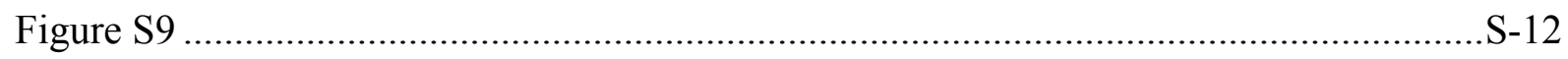

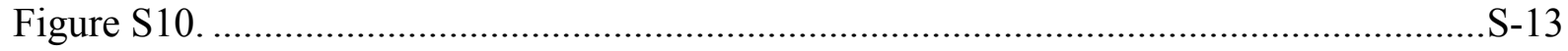

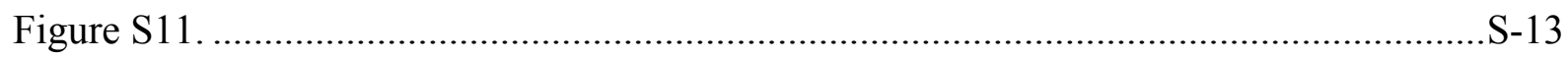

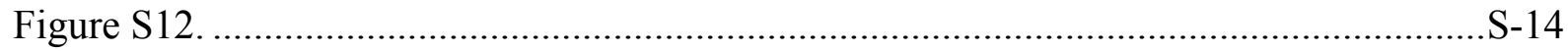

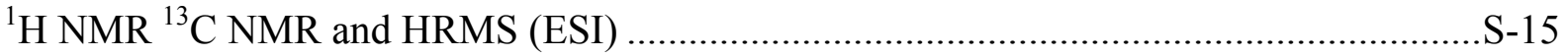

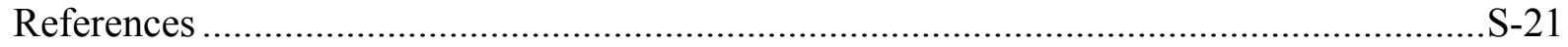




\section{Materials and Instruments}

Monomethoxypoly(ethyleneglycol) $\left(\mathrm{PEG}_{5 \mathrm{k}}, M_{\mathrm{n}}=5000\right)$, 3-Bromopropionyl chloride, ethyl chloroformate, 4-Hydroxymethyl phenyl boronic acid, hydrogen peroxide, and 2,2-bis(hydroxyl methyl)propionic acid were purchased from Alfa Aesar and used as received. 4-Hydroxymethylphenyl boronic acid pinacol ester was synthesized according to literature. ${ }^{1}$ The ROS were prepared following reported literature. ${ }^{2}$ We dried dichloromethane (DCM), dimethylformamide (DMF), 1,8-diazabicyclo[5.4.0]undec-7-ene(DBU), triethylamine over calcium hydride for 24 hours at room temperature and distilled them under reduced pressure. The thiourea catalyst (TU) was synthesized and recrystallized from dry methylene chloride as reported previously. ${ }^{3}$ Tetrahydrofuran (THF) was dried by refluxing over a benzophenone-sodium mixture until a deep blue appearance and then subject to distillation.

Absorption spectra were recorded using a Hitachi U-4100 UV-vis spectrophotometer (Kyoto, Japan) in $1 \mathrm{~cm}$ path length quartz cuvettes. ${ }^{1} \mathrm{H}$ and ${ }^{13} \mathrm{C}$ NMR spectra were recorded on an Invoa-400 (Invoa 400) spectrometer and referenced to solvent signals. Mass spectra were measured on a LCQ/Advantage HPLC-Mass spectrotometer. The number-average molecular weight $\left(M_{\mathrm{n}}\right)$ and molecular distribution (polydispersity index, PDI $\left.=M_{\mathrm{w}} / M_{\mathrm{n}}\right)$ of polymers were determined at room temperature (RT) using a Waters GPC liquid chromatograph (Waters, USA) equipped with four TSK HXL series of polystyrene divinylbenzene gel columns $(300 \times 7.8 \mathrm{~mm})$. Calibration was established with polystyrene standards from Polymer Laboratories. THF was used as solvent with a flow rate of $1 \mathrm{~mL}$ $\min ^{-1}$. Scanning electron microscopy (SEM) images were obtained on an S-4800 scanning electron microscope (Hitachi) with a working voltage of $5 \mathrm{kV}$. A drop of the micelle aqueous solution $\left(0.05 \mathrm{mg} \mathrm{mL}^{-1}\right)$ was deposited onto a silicon slice and allowed to dry at RT before 
measurement. The mean size of the micelles was determined by dynamic light scattering (DLS) using a Malvern Nano S instrument (Malvern, UK).

\section{The detailed synthesis and structural characterizations of (1)-(6)}

\section{Synthesis of (4-(4,4,5,5-Tetramethyl-1,3,2-dioxaborolan-2-yl)phenyl)methanol (1)}

(4-(Hydroxymethyl)phenyl)boronic acid (3.81 g, $25 \mathrm{mmol})$ and pinacol (3.54 g, $30 \mathrm{mmol})$ were mixed in toluene $(300 \mathrm{~mL})$ in a round-bottomed flask. A Dean stark head was fitted and the reaction was heated under reflux condition for 2 hours. The mixture was allowed to cool to room temperature, and then washed with water $(3 \times 150 \mathrm{~mL})$. The organic layer was condensed under reduced pressure and DCM $(100 \mathrm{~mL})$ was added. This was washed with water $(3 \times 150 \mathrm{~mL})$, dried over $\mathrm{MgSO}_{4}$ and filtered. The solvents were again removed under reduced pressure to yield compound 1 as a white solid (4.84 g, 82.7\%). ${ }^{1} \mathrm{H}$ NMR (400 MHz, $\left.\mathrm{CDCl}_{3}\right): \delta 7.84(\mathrm{~d}, 2 \mathrm{H}, \mathrm{ArH}), 7.40(\mathrm{~d}, 2 \mathrm{H}, \mathrm{ArH}), 4.75\left(\mathrm{~s}, 2 \mathrm{H}, \mathrm{PhCH}_{2} \mathrm{OH}\right), 1.37(\mathrm{~s}, 12 \mathrm{H}$, $\left.\left(\mathrm{CH}_{3}\right)_{2} \mathrm{CC}\left(\mathrm{CH}_{3}\right)_{2}\right) ;{ }^{13} \mathrm{C}$ NMR $\left(100 \mathrm{MHz}, \mathrm{CDCl}_{3}\right): \delta 143.9,134.9,125.96,83.72,65.00,24.73$. Synthesis of 4-(4,4,5,5-tetramethyl-1,3,2-dioxaborolan-2-yl)benzyl-3-bromo-propanoate (2) synthesized by esterfication of (1) with 3-Bromopropionyl chloride. Typically, triethylamine (6.07g, $60 \mathrm{mmol}),(4-(4,4,5,5-T e t r a m e t h y l-1,3,2-d i o x a b o r o l a n-2-y l)$ phenyl)methanol (9.36 g, $40 \mathrm{mmol})$, and dry THF (200 $\mathrm{mL})$ were charged into a $500 \mathrm{~mL}$ round-bottom flask, cooled to $0{ }^{\circ} \mathrm{C}$ in an ice water bath, and then 3-Bromopropionyl chloride $(6.84 \mathrm{~g}, 40 \mathrm{mmol})$ in $100 \mathrm{~mL}$ dry THF was added dropwise over a period of $1 \mathrm{~h}$ under vigorous magnetic stirring. After the addition was completed, the reaction mixture was stirred at room temperature overnight. After 
filtration and evaporating all the solvents, the residues were diluted with ethyl acetate and washed twice with water and brine, respectively. The organic layer was dried over anhydrous $\mathrm{MgSO}_{4}$, filtered, concentrated and finally purified by silica gel column chromatograph using ethyl acetate/petroleum ether $(1 / 3 \mathrm{v} / \mathrm{v})$ as the eluent, affording (2) as a yellowish liquid $(9.48$ g, yield: 71.6\%). ${ }^{1} \mathrm{H}$ NMR (400 MHz, $\left.\mathrm{CDCl}_{3}\right): \delta 7.79(\mathrm{~d}, 2 \mathrm{H}, \mathrm{ArH}), 7.34(\mathrm{~d}, 2 \mathrm{H}, \mathrm{ArH}), 5.17$ (s, 2H, $\left.\mathrm{OCH}_{2} \mathrm{Ar}\right), 3.74$ (t, 2H, $\left.\mathrm{BrCH}_{2} \mathrm{C}\right), 2.84\left(\mathrm{t}, 2 \mathrm{H}, \mathrm{CCH}_{2} \mathrm{CO}\right), 1.33\left(\mathrm{~s}, 12 \mathrm{H},\left(\mathrm{CH}_{3}\right)_{2} \mathrm{CC}\left(\mathrm{CH}_{3}\right)_{2}\right)$.

${ }^{13} \mathrm{C}$ NMR $\left(100 \mathrm{MHz}, \mathrm{CDCl}_{3}\right): \delta 176.18,138.40,135.00,131.22,127.33,83.93,66.66,37.43$, $29.66,24.79$.

Synthesis of 4-(4,4,5,5-tetramethyl-1,3,2-dioxaborolan-2-yl)benzyl 3-azido propanoate $(\text { Bpe-N })_{3}$ (3)

Compound 2 (4.43 g, 12.0mmol) and sodium azide (1.56 g, 24.0mmol) were dissolved in DMF $(15 \mathrm{~mL})$, and the mixture was stirred at room temperature for 24 hours. The solution was added DCM $(100 \mathrm{~mL})$ and reversed extraction with water three times $(3 \times 100 \mathrm{~mL})$. The organic phase was dried over anhydrous $\mathrm{MgSO}_{4}$, filtered and evaporated to dryness. The product was collected as a yellow solid powder. Yield: $3.58 \mathrm{~g}(90.1 \%) .{ }^{1} \mathrm{H}$ NMR (400 MHz, $\left.\mathrm{CDCl}_{3}\right): \delta 7.81(\mathrm{~d}, 2 \mathrm{H}, \mathrm{ArH}), 7.36(\mathrm{~d}, 2 \mathrm{H}, \mathrm{ArH}), 5.18\left(\mathrm{~s}, 2 \mathrm{H}, \mathrm{OCH}_{2} \mathrm{Ar}\right), 2.86(\mathrm{t}, 2 \mathrm{H}$, $\left.\mathrm{CCH}_{2} \mathrm{CO}\right), 1.88\left(\mathrm{t}, 2 \mathrm{H}, \mathrm{N}_{3} \mathrm{CH}_{2} \mathrm{C}\right), 1.35\left(\mathrm{~s}, 12 \mathrm{H},\left(\mathrm{CH}_{3}\right)_{2} \mathrm{CC}\left(\mathrm{CH}_{3}\right)_{2}\right) .{ }^{13} \mathrm{C}$ NMR $(100 \mathrm{MHz}$, $\left.\mathrm{CDCl}_{3}\right): \delta=176.18,138.40,135.00,131.22,127.33,83.93,66.66,45.38,29.66,24.79$.

\section{Synthesis of 2, 2-Bis(hydroxyl methyl)propionate (4)}

In a $250 \mathrm{~mL}$ round-bottom flask, 2, 2-bis(hydroxyl methyl)-propionic acid (2.24 g, 16.72 mmol), KOH (1.01 g, $18.04 \mathrm{mmol})$ and DMF $(20 \mathrm{~mL})$ was added. The mixture was stirred at $100{ }^{\circ} \mathrm{C}$ for $2 \mathrm{~h}$, then propargyl bromide $(2.13 \mathrm{~g}, 18.04 \mathrm{mmol})$ was added dropwise over 30 
min. After 72 hours of reaction, the reaction mixture was filtered, the solvent was evaporated under reduced pressure, and the residues were dissolved in $50 \mathrm{~mL}$ of DCM and extracted three times with saturated salt water $(3 \times 10 \mathrm{~mL})$. The organic phase was concentrated to yield crude product, which was purified by column chromatography (eluent: ethyl acetate/petroleum ether $=1 / 5, \mathrm{v} / \mathrm{v})$. Yield: $1.3 \mathrm{~g}(45.14 \%) .{ }^{1} \mathrm{H}$ NMR $\left(400 \mathrm{MHz}, \mathrm{CDCl}_{3}\right): \delta=$ $4.76\left(\mathrm{~d}, 2 \mathrm{H}, \mathrm{CHCCH}_{2} \mathrm{CO}\right), 3.91\left(\mathrm{~d}, 2 \mathrm{H}, \mathrm{CH}_{2} \mathrm{OH}\right), 3.72\left(\mathrm{~d}, 2 \mathrm{H}, \mathrm{CH}_{2} \mathrm{OH}\right), 2.51(\mathrm{t}, 1 \mathrm{H}$, $\left.\mathrm{CHCCH}_{2} \mathrm{CO}\right), 1.11\left(\mathrm{~s}, 3 \mathrm{H}, \mathrm{CH}_{3} \mathrm{CC}\right) .{ }^{13} \mathrm{C} \mathrm{NMR}\left(400 \mathrm{MHz}, \mathrm{CDCl}_{3}\right): \delta=175.01,75.20,67.82$, $52.43,49.29,16.95$.

\section{Synthesis of 5-Methyl-5-propargylxycarbonyl-1,3-dioxane-2-one (MPC) (5)}

Compound 4 (1.18 g, $6.88 \mathrm{mmol})$ was mixed with ethyl chloroformate (1.48 g, $13.76 \mathrm{mmol})$ and THF $(20 \mathrm{~mL})$ in a sealed vessel that was purged with nitrogen and cooled in an ice bath. After stirring an hour, triethylamine $(1.39 \mathrm{~g}, 13.76 \mathrm{mmol})$ was added drop wise over 30 -min period under nitrogen atmosphere. The reaction was conducted at $0{ }^{\circ} \mathrm{C}$ with stirring for $3 \mathrm{~h}$, then at $25{ }^{\circ} \mathrm{C}$ under stirring overnight. The solution was then subject to filtered, evaporated to dryness, and the as-obtained product was precipitated in a mixture of ethyl acetate and diethyl ether (1:1) as white crystals. Yield: $1.24 \mathrm{~g}(91.05 \%) .{ }^{1} \mathrm{H}$ NMR $\left(400 \mathrm{MHz}, \mathrm{CDCl}_{3}\right): \delta=$ 4.79-4.80 (d, 2H, $\left.\mathrm{CHCCH}_{2} \mathrm{CO}\right), 4.71-4.74\left(\mathrm{~d}, 2 \mathrm{H}, \mathrm{CH}_{2} \mathrm{OCO}\right), 4.22-4.25$ (d, 2H, $\left.\mathrm{CH}_{2} \mathrm{OCO}\right)$, 2.54-2.55 (t, $\left.1 \mathrm{H}, \mathrm{CHCCH}_{2} \mathrm{CO}\right), 1.37$ (s, 3H, $\left.\mathrm{CH}_{3} \mathrm{CC}\right) \cdot{ }^{13} \mathrm{C} \mathrm{NMR}\left(100 \mathrm{MHz}, \mathrm{CDCl}_{3}\right): \delta=$ $170.31,147.21,76.35,75.94,72.70,53.47,40.17,17.39$.

\section{Synthesis of PEG-b-poly(MPC) (6)}

The ring-opening polymerization of MPC was carried out under an inert atmosphere of nitrogen using standard Schlenk-line technique. In a typical experiment, MPC $(0.594 \mathrm{~g}, 3$ 
mmol), PEG $5 \mathrm{k}(0.601 \mathrm{~g}, 0.12 \mathrm{mmol}), \mathrm{TU}(0.055 \mathrm{~g}, 0.15 \mathrm{mmol}), \mathrm{DBU}(0.005 \mathrm{~g}, 0.03 \mathrm{mmol})$ and dried DCM $(10 \mathrm{~mL})$ were placed in a dried Schlenk tube fitted with a rubber septum. The solution was further degassed through three freeze-pump-thaw cycles. The resulting mixture was stirred at room temperature for $7 \mathrm{~h}$, followed by precipitation in ice-cold diethyl ether and centrifugation. The resulting product was collected by filtration and dried under vacuum to yield a white powder. Yield: $1.1 \mathrm{~g}(92.0 \%) .{ }^{1} \mathrm{H}$ NMR $\left(400 \mathrm{MHz}, \mathrm{CDCl}_{3}\right): \delta=4.73(\mathrm{~d}$, $\left.\mathrm{OCH}_{2} \mathrm{CCH}\right), 4.28-4.32\left(\mathrm{~m}, \mathrm{OC}(\mathrm{O}) \mathrm{OCH}_{2}\right), 3.65\left(\mathrm{~s}, \mathrm{OCH}_{2} \mathrm{CH}_{2} \mathrm{O}\right), 3.38\left(\mathrm{~s}, \mathrm{CH}_{3} \mathrm{O}\right), 2.55(\mathrm{~s}$, $\left.\mathrm{CH}_{2} \mathrm{CCH}\right), 2.19(\mathrm{~s}, \mathrm{OH}), 1.29\left(\mathrm{~s}, \mathrm{CH}_{3}\right)$. GPC (THF, RI): $M_{\mathrm{n}}(\mathrm{PDI})=7263 \mathrm{~g} \mathrm{~mol}^{-1}(1.04)$. 


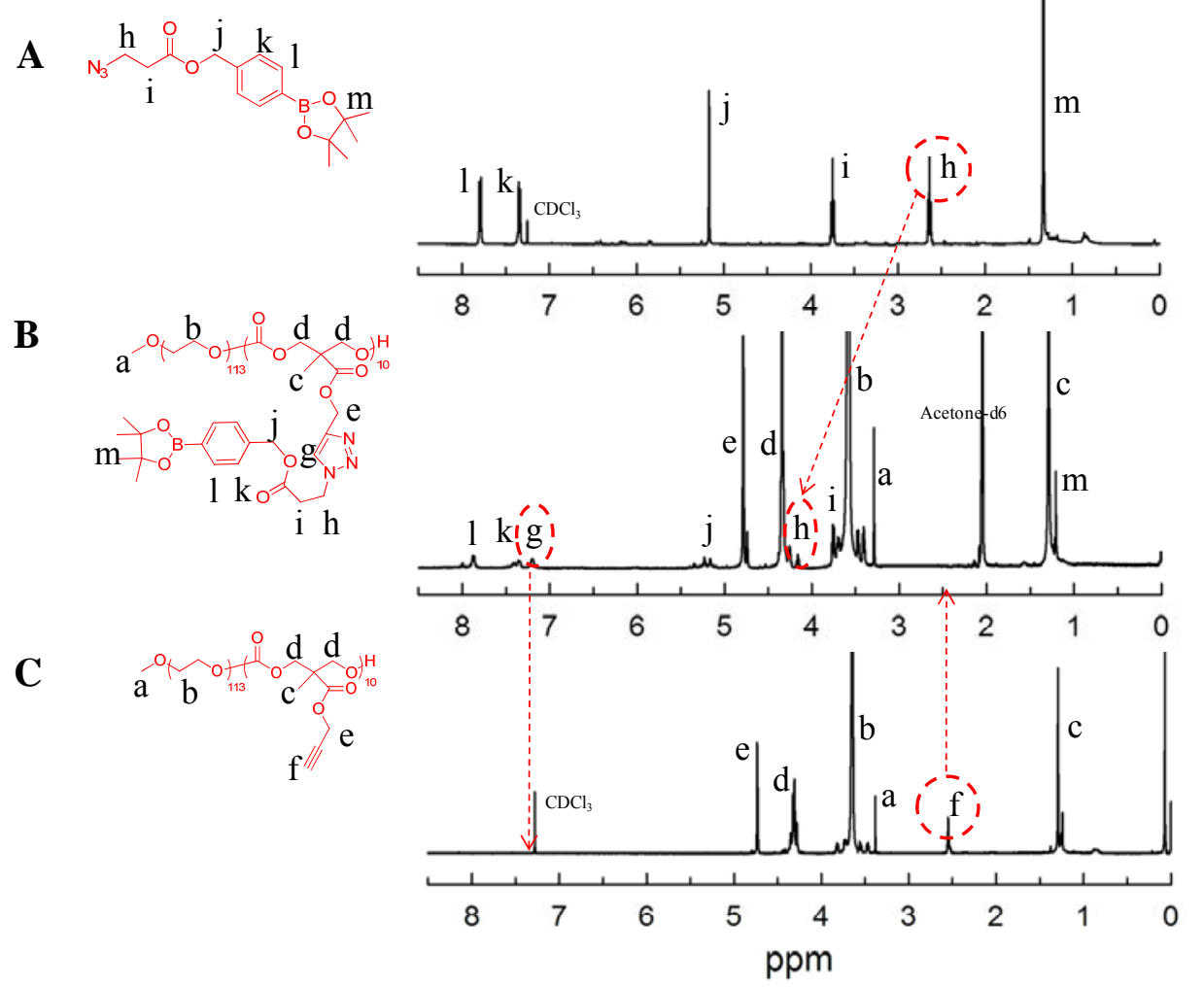

Figure S1. ${ }^{1} \mathrm{H}$ NMR spectra of (A) Bpe-N ${ }_{3}$, (B) PMPC-Bpe, and (C) PEG-b-poly(MPC).

Table S1. Molecular Characteristics of Amphiphiles PEG- $b$-poly(MPC) and PMPC-Bpe

\begin{tabular}{|c|c|c|c|c|}
\hline Entry & $M_{\mathrm{w}} / M_{\mathrm{n}}^{\mathrm{a}}$ & $M_{\mathrm{n}, \mathrm{GPC}}{ }^{\mathrm{a}}$ & $M_{\mathrm{n}, \mathrm{NMR}}^{\mathrm{b}}$ & $\mathrm{CMC}^{\mathrm{c}}\left(\mathrm{mg} \mathrm{mL}^{-1}\right)$ \\
\hline PEG- $b-$ poly(MPC) & 1.0483 & 7263 & 6984 & 0.0116 \\
\hline PMPC-Bpe & 1.0809 & 11171 & 10293 & 0.0129 \\
\hline \multicolumn{5}{|c|}{$\begin{array}{l}\text { a Both molecular weight }\left(M_{\mathrm{n}, \mathrm{GPC}}\right) \text { and the polydispersity }\left(M_{\mathrm{w}} / M_{\mathrm{n}}\right) \text { of the amphiphiles were determined by GPC. } \\
{ }^{\mathrm{b}} M_{\mathrm{n}, \mathrm{NMR}} \text { was determined by }{ }^{1} \mathrm{H} \text { NMR. } \\
{ }^{\mathrm{c}} \mathrm{CMC} \text { : the critical micellar concentration of the amphiphiles was determined by fluorescence spectroscopy (Figure S3). }\end{array}$} \\
\hline
\end{tabular}




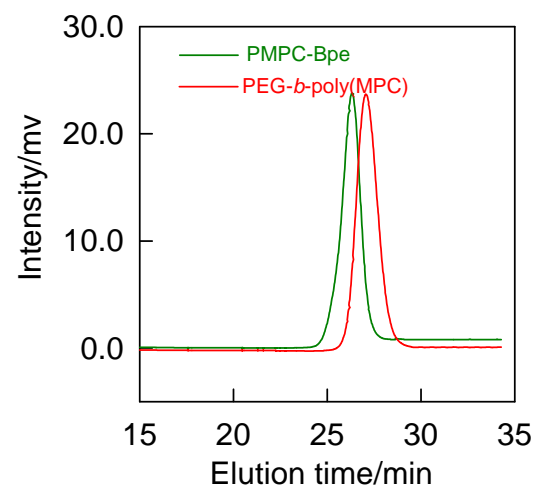

Figure S2. GPC traces of PEG-b-poly(MPC) (red line) and PMPC-Bpe (dark green line).
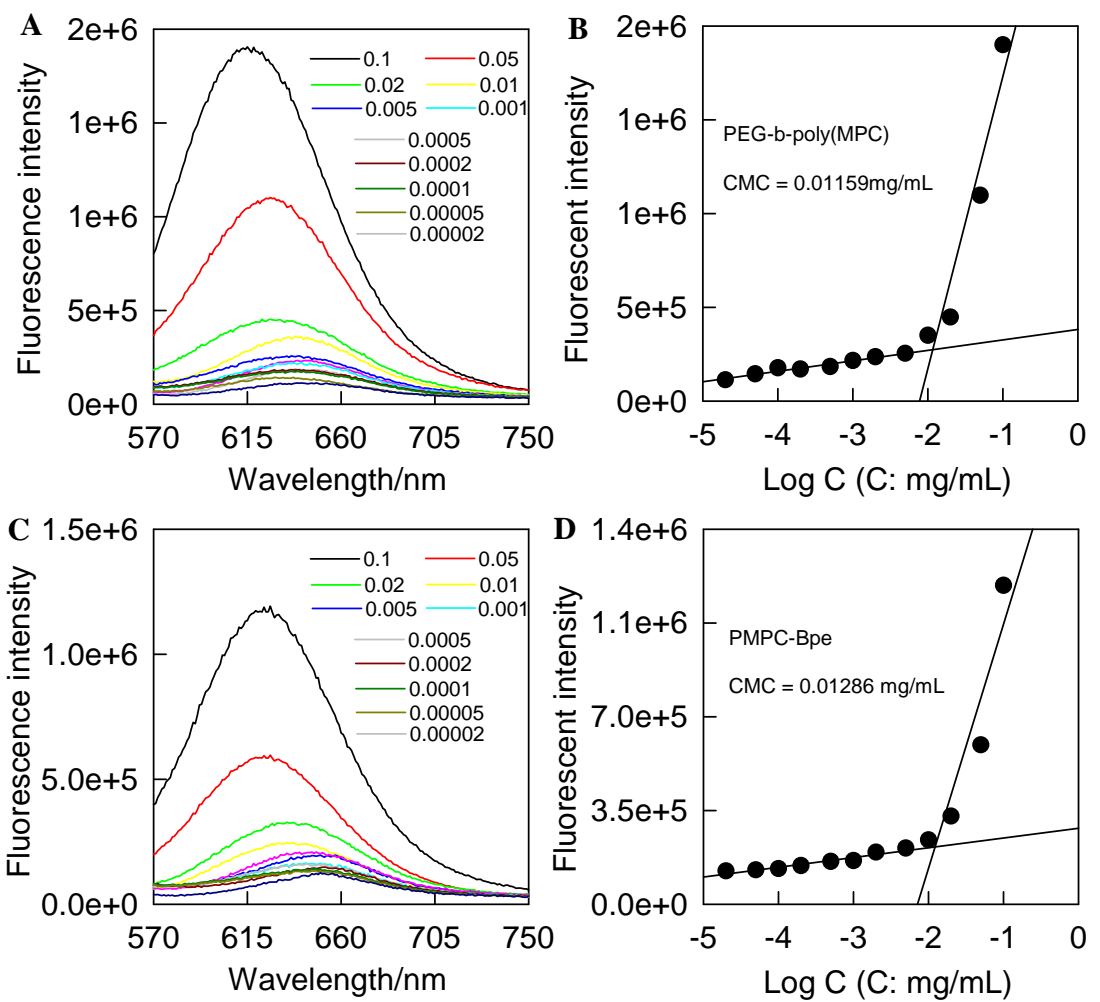

Figure S3. Fluorescence emission spectra of Nile Red in (A) PEG-b-poly(MPC) micelles and (C) PMPC-Bpe micelles of varying concentrations and the relevant emission intensity at $630 \mathrm{~nm}$ versus the $\log$ of concentration for (B) PEG-b-poly(MPC) micelles and (D) PMPC-Bpe micelles. 

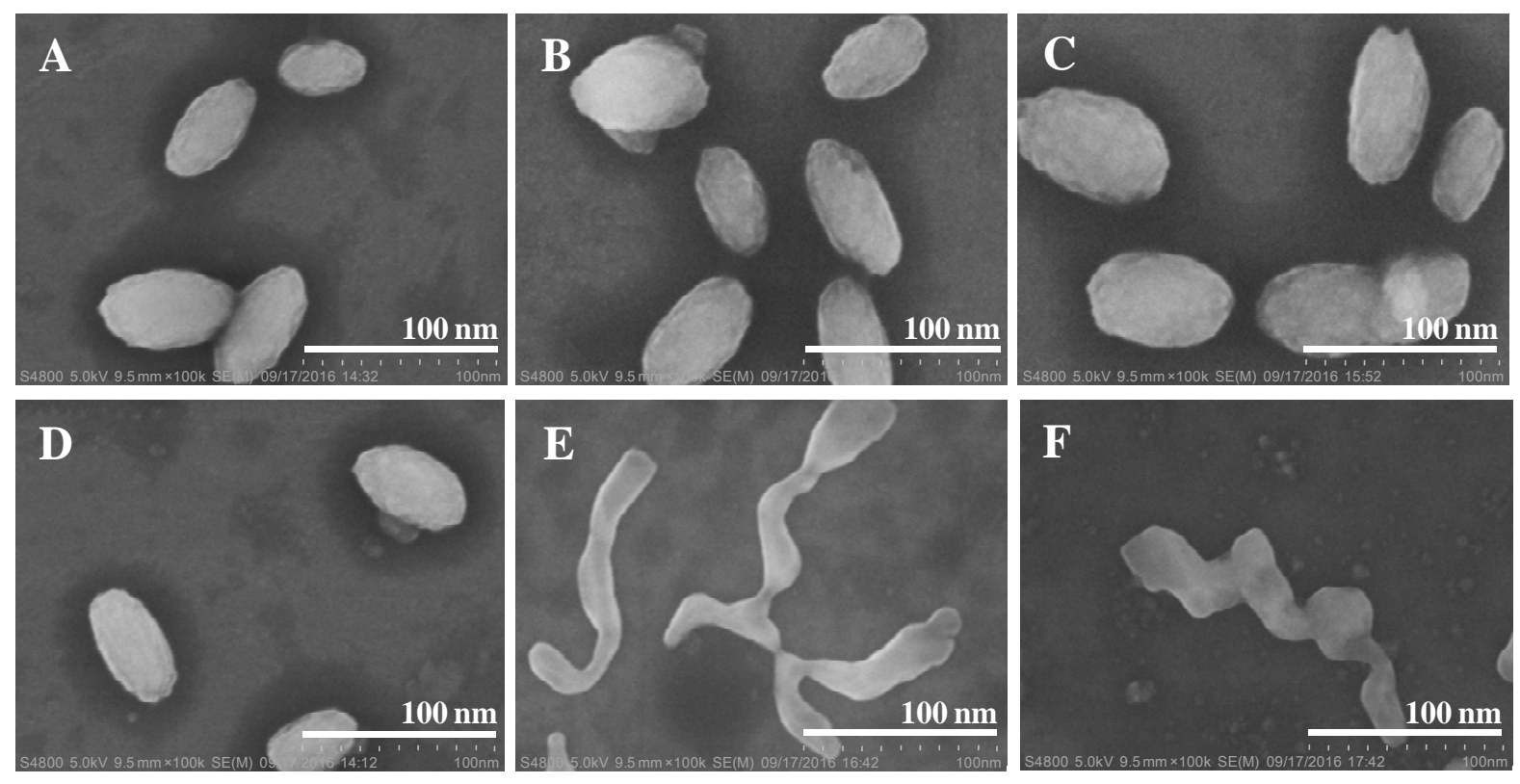

Figure S4. SEM photographs of the micelles: PEG-b-poly(MPC) (A), PMPC-Bpe (B), and PMPC-Bpe@Amylose system (C). Images (D-F) are the different micelles (A), (B), and (C) treated by $\mathrm{H}_{2} \mathrm{O}_{2}$, correspondingly. Scale bar: $100 \mathrm{~nm}$.
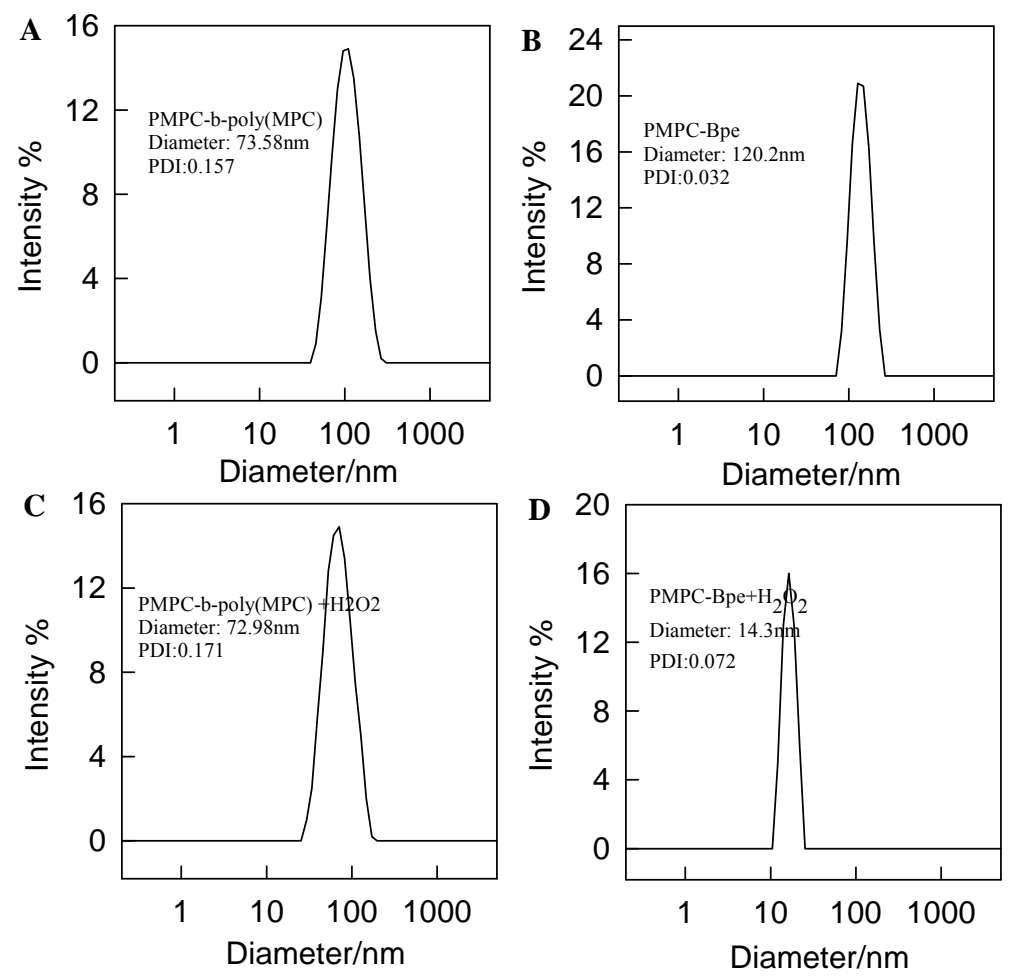

Figure S5. Mean size distributions of the micelles determined by DLS: (A) PMPC-Bpe, (C) 
PEG-b-poly(MPC), PMPC-Bpe after 90 min treated by $\mathrm{H}_{2} \mathrm{O}_{2}(\mathrm{~B})$, and PMPC-Bpe treated by $\mathrm{H}_{2} \mathrm{O}_{2}$ (D).

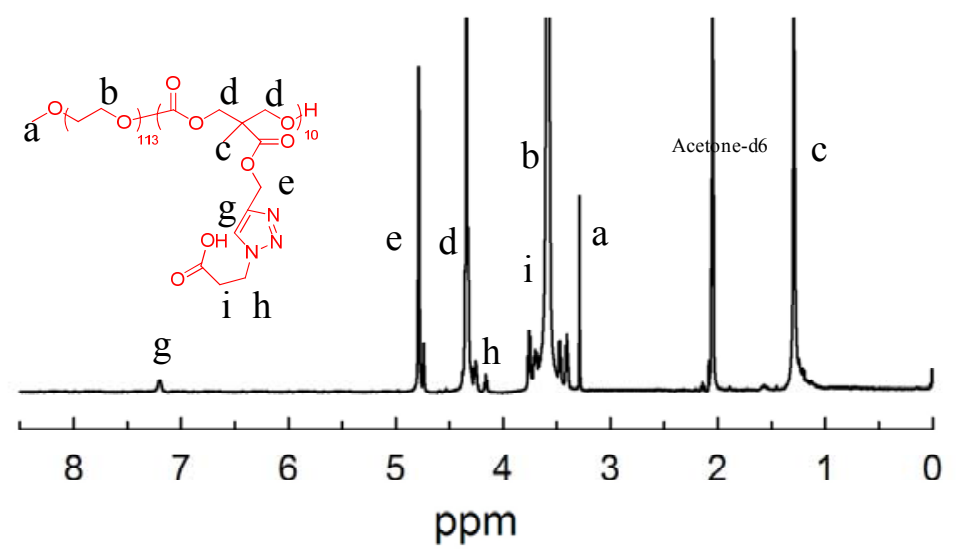

Figure S6. ${ }^{1} \mathrm{H}$ NMR of PMPC-Bpe micelles $\left(0.5 \mathrm{mg} \mathrm{mL}^{-1}\right)$ treated with $\mathrm{H}_{2} \mathrm{O}_{2}(1 \mathrm{mM})$. (The product was allowed to dialyze in aqueous solution and lyophilize for ${ }^{1} \mathrm{H}$ NMR detection.)
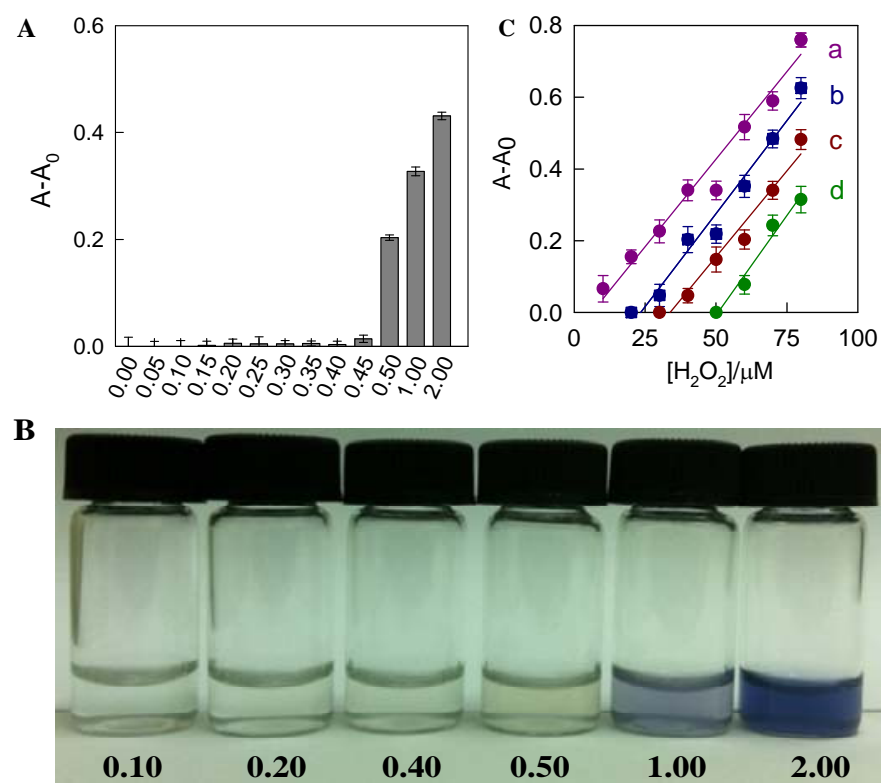

Figure S7. Trapping capacity of PMPC-Bpe micelle $\left(2.0 \mathrm{mg} \mathrm{mL} \mathrm{m}^{-1}\right)$ to different concentrations of amylose $(0,0.05,0.10,0.15,0.20,0.25,0.30,0.35,0.40,0.45,0.50,1.0$, and $2.0 \mathrm{mg} \mathrm{mL}{ }^{-1}$ ) were researched. As observed corresponding absorbance of amylose- $\mathrm{KI} / \mathrm{I}_{2}$ 
complex at $574 \mathrm{~nm}(\mathrm{~A})$ and observed by the naked eye (B). (C) The linear ranges of micelle system trapped different mount of amylose ((a) 0.45 , (b) 0.35 , (c) 0.25 , and (d) $0.15 \mathrm{mg} \mathrm{mL}^{-1}$ ) between absorbance intensity and concentrations of $\mathrm{H}_{2} \mathrm{O}_{2}$. Where $\mathrm{A}_{0}$ and $\mathrm{A}$ are the absorbance of amylose- $\mathrm{KI} / \mathrm{I}_{2}$ complex at $574 \mathrm{~nm}$ in the absence or presence of $\mathrm{H}_{2} \mathrm{O}_{2}$. All of the experiments were performed with the same concentration of $\mathrm{KI} / \mathrm{I}_{2}(1 \mathrm{mM})$.
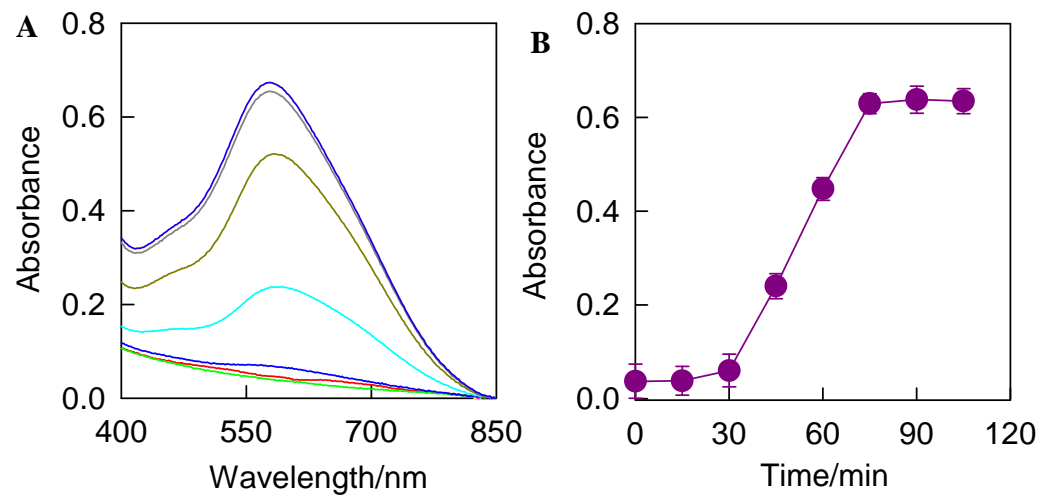

Figure S8 Absorption spectra (A) and corresponding line graph (B) were the time history of the PMPC-Bpe micelle $\left(0.5 \mathrm{mg} \mathrm{mL}^{-1}\right)$ to the same concentrations of $\mathrm{H}_{2} \mathrm{O}_{2}(1 \mathrm{mM})$. Soon afterwards, the solution was treated by $\mathrm{KI} / \mathrm{I}_{2}$ at the time of $0,15,30,45,60,75$, and $90 \mathrm{~min}$, respectively. Absorbance intensity was recorded at $574 \mathrm{~nm}$.

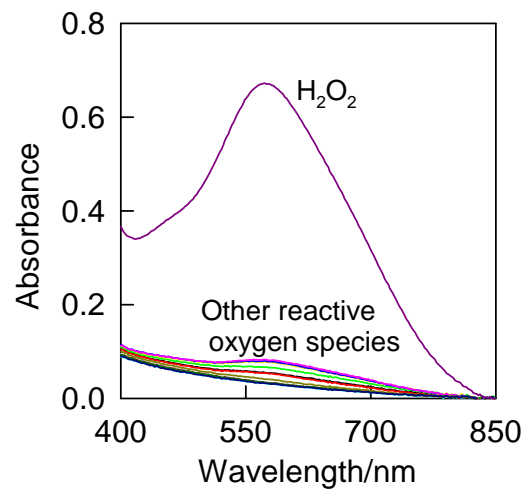

Figure S9 The selectivity of PMPC-Bpe micelle $\left(0.5 \mathrm{mg} \mathrm{mL}^{-1}\right)$ was toward various ROS 
$\left(\mathrm{CH}_{3} \mathrm{CO}_{3} \mathrm{H},{ }^{1} \mathrm{O}_{2}, \cdot \mathrm{O}^{t} \mathrm{Bu}, \cdot \mathrm{OH}, \mathrm{O}_{2}^{--}, \mathrm{HClO}, \mathrm{Fe}^{3+}, \mathrm{NO}^{2-}, \mathrm{NO}^{3-}\right.$, tert-butyl hedroperoxide (TBHP), and NO). The absorbance of PMPC-Bpe micelle in PBS (pH 7.4, $20 \mathrm{mM}$ ) solution and treated by $\mathrm{KI} / \mathrm{I}_{2} 90 \mathrm{~min}$ later after addition of $\mathrm{ROS}(1 \mathrm{mM})$, respectively.

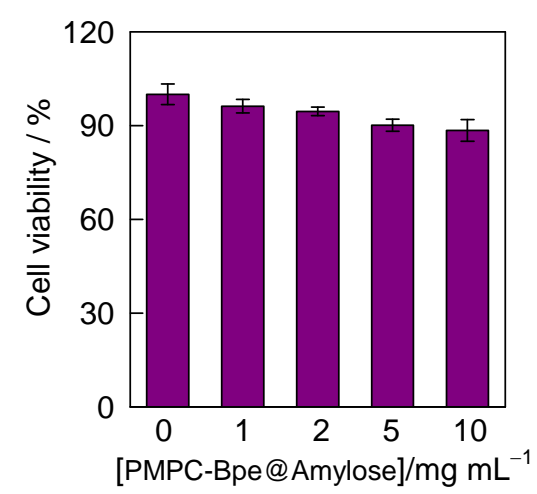

Figure S10. Cell viability of normal human embryonic kidney cell (HEK 293) after $24 \mathrm{~h}$ treated with different concentrations of PMPC-Bpe@Amylose at $37{ }^{\circ} \mathrm{C}$.
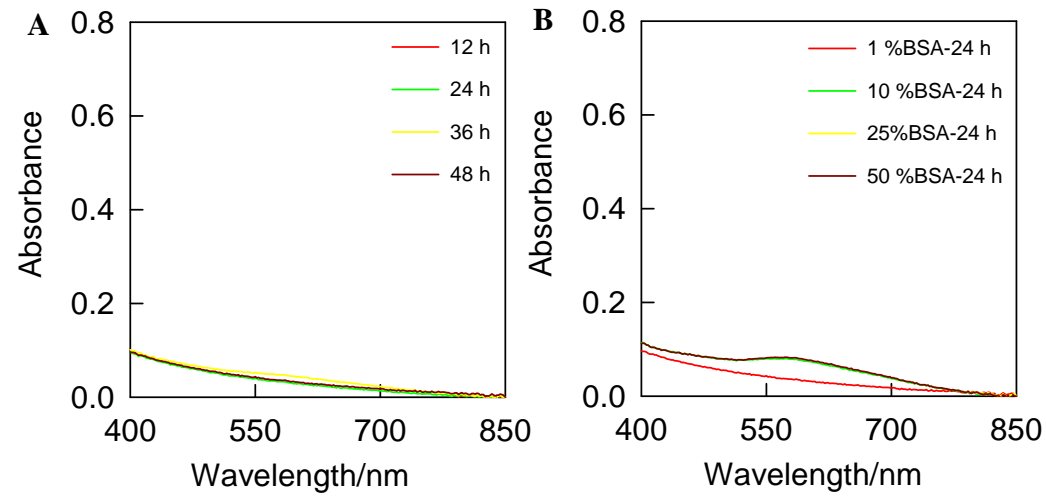

Figure S11. (A) Effect of human cell lysate-contained biological fluids on PMPC-Bpe@Amylose at different times (12, 24, 36, and 48 h). (B) Effect of different concentration of bovine serum albumin on PMPC-Bpe@Amylose at the same time. All the needed PMPC-Bpe@Amylose concentration was $0.5 \mathrm{mg} \mathrm{mL}^{-1}$ and the $\mathrm{KI} / \mathrm{I}_{2}$ was $1 \mathrm{mM}$. 

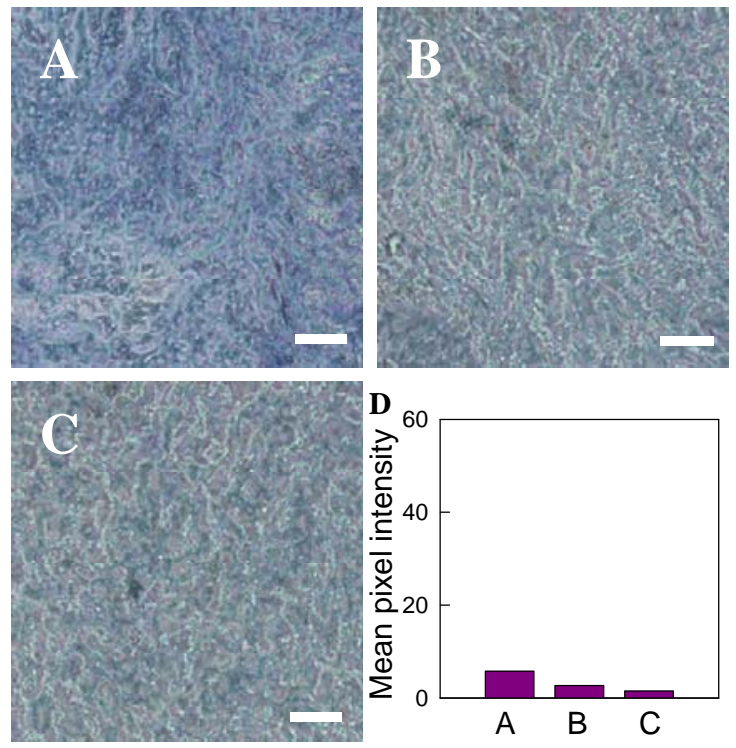

Figure S12. Three kinds of actual juxtacancerous samples were put into diagnosing. (A-C) were the juxtacancerous tissue slices of breast cancer, colon cancer, and cervical, respectively. The tissue samples were incubated with the micelle for 90 min and then treated by $\mathrm{KI} / \mathrm{I}_{2}$. As mentioned above, the needed micelle concentration was $0.5 \mathrm{mg} \mathrm{mL}^{-1}$ and the $\mathrm{KI} / \mathrm{I}_{2}$ was 1 mM. Scale bar: $200 \mathrm{~mm}$. (D) Quantification and comparison of the relative absorbance intensity of slices $(\mathrm{A}-\mathrm{C})$, correspondingly. The images were obtained from the TE2000 microscope (Nikon Instruments Inc, Japan) $(10 \times)$. 


\section{${ }^{1} \mathrm{H}$ NMR ${ }^{13} \mathrm{C}$ NMR and HRMS (ESI)}

$$
\text { V V }
$$

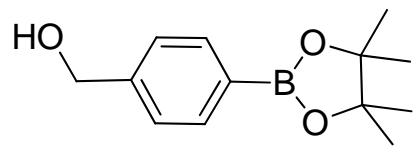

Chemical Formula: $\mathrm{C}_{13} \mathrm{H}_{19} \mathrm{BO}_{3}$

Molecular Weight: 234.10

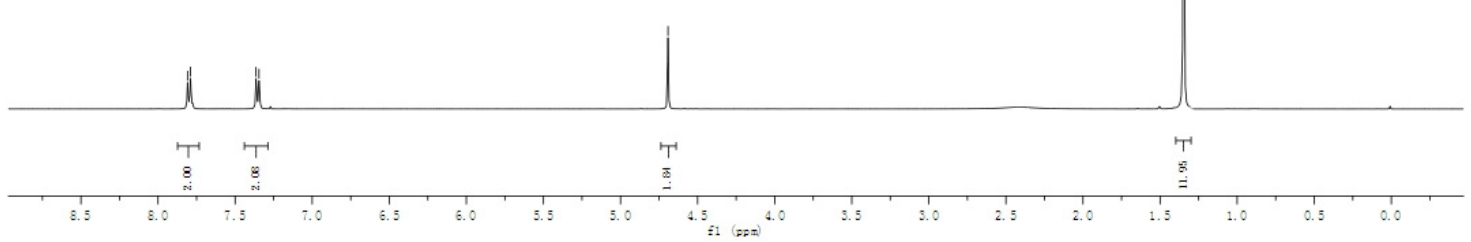

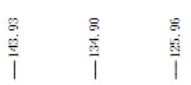

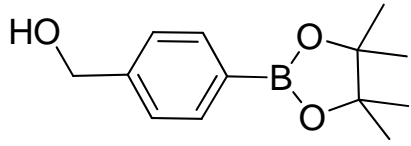

Chemical Formula: $\mathrm{C}_{13} \mathrm{H}_{19} \mathrm{BO}_{3}$

Molecular Weight: 234.10
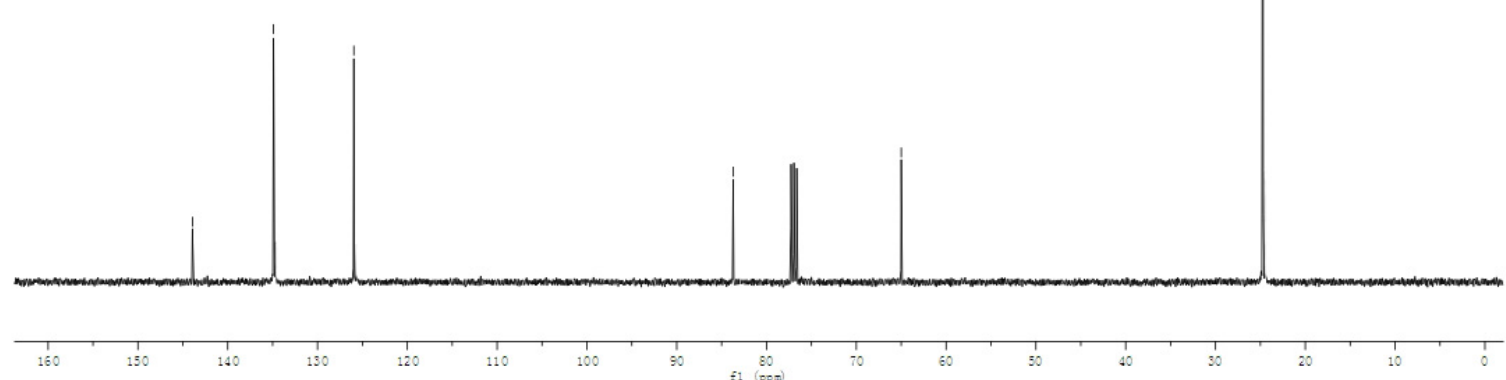
zhwj-140903-234 \#7 RT: 1.35 AV: 1 NL: $2.78 E 6$
T: + c El Full ms $[49.50-500.50]$
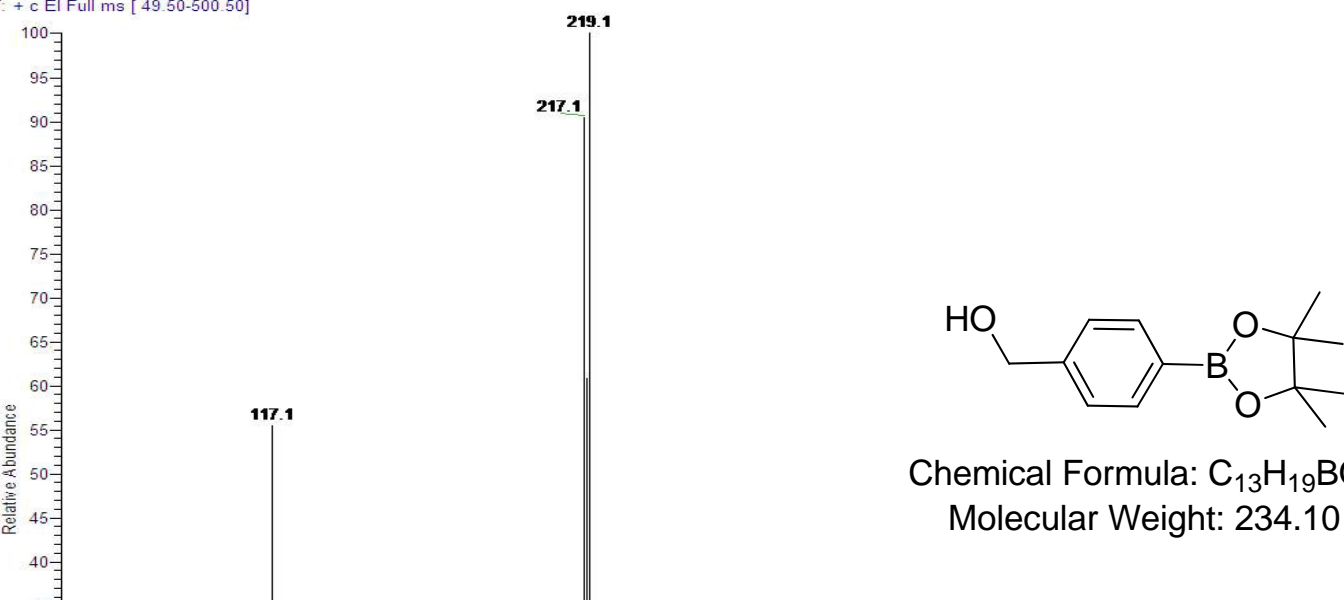

Chemical Formula: $\mathrm{C}_{13} \mathrm{H}_{19} \mathrm{BO}_{3}$ Molecular Weight: 234.10

繁䕎

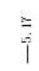

新

瑟㛺

$\frac{n}{i}$<smiles>CC1(C)OB(c2ccc(COC(=O)CCBr)cc2)OC1(C)C</smiles>

Chemical Formula: $\mathrm{C}_{16} \mathrm{H}_{22} \mathrm{BBrO}_{4}$

Molecular Weight: 369.06

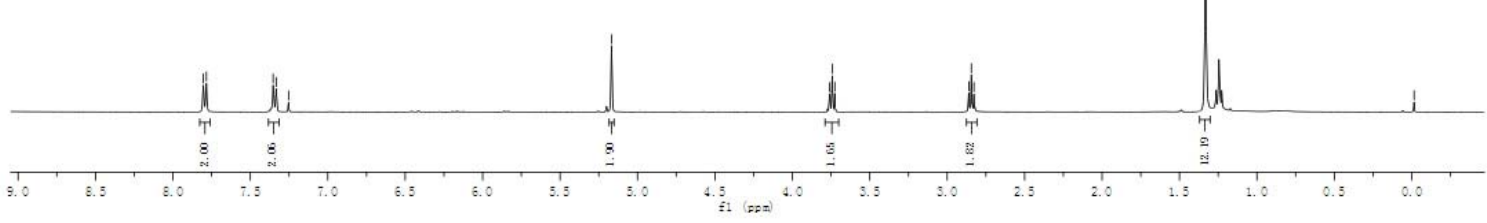

S-16 

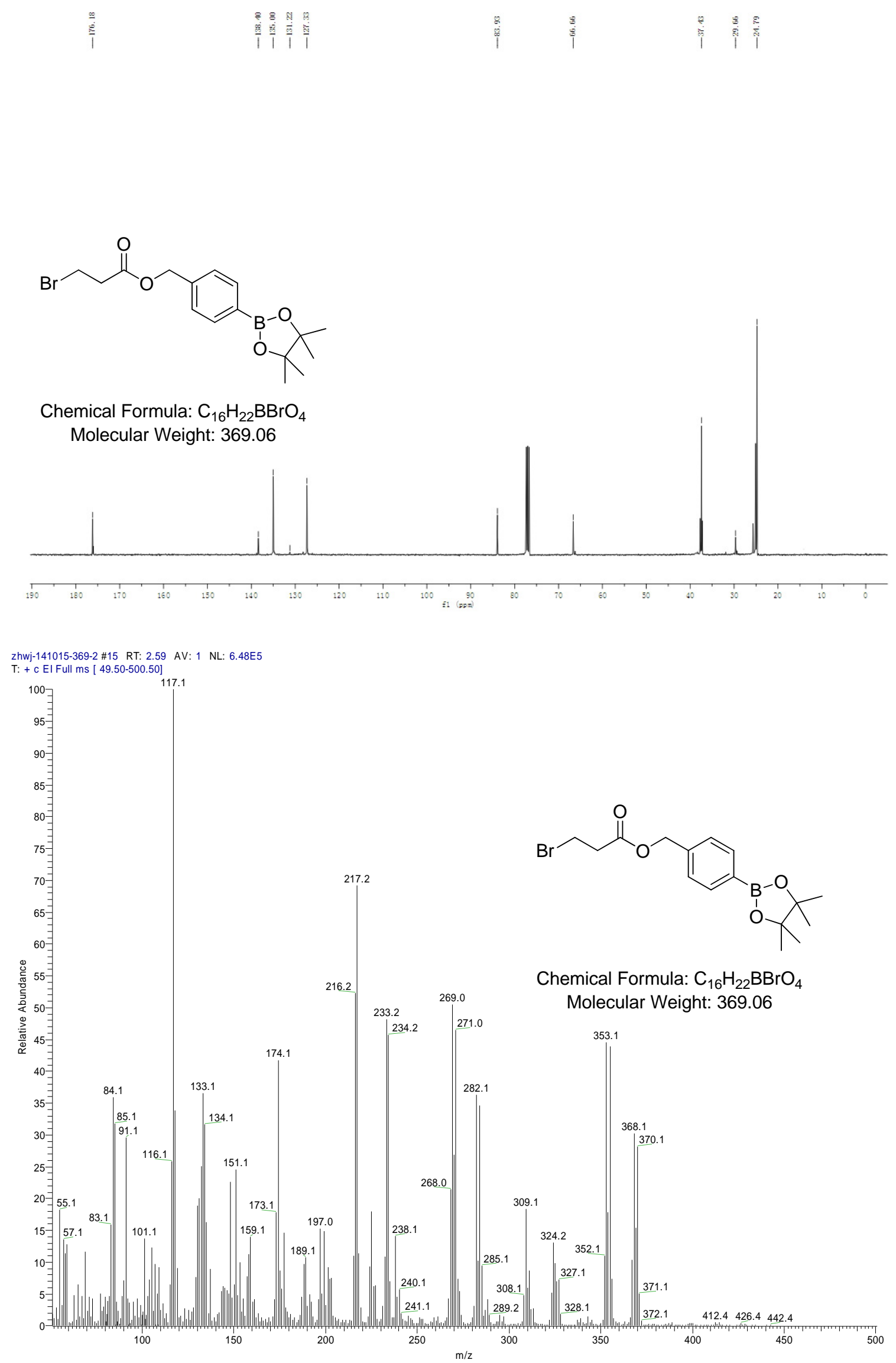

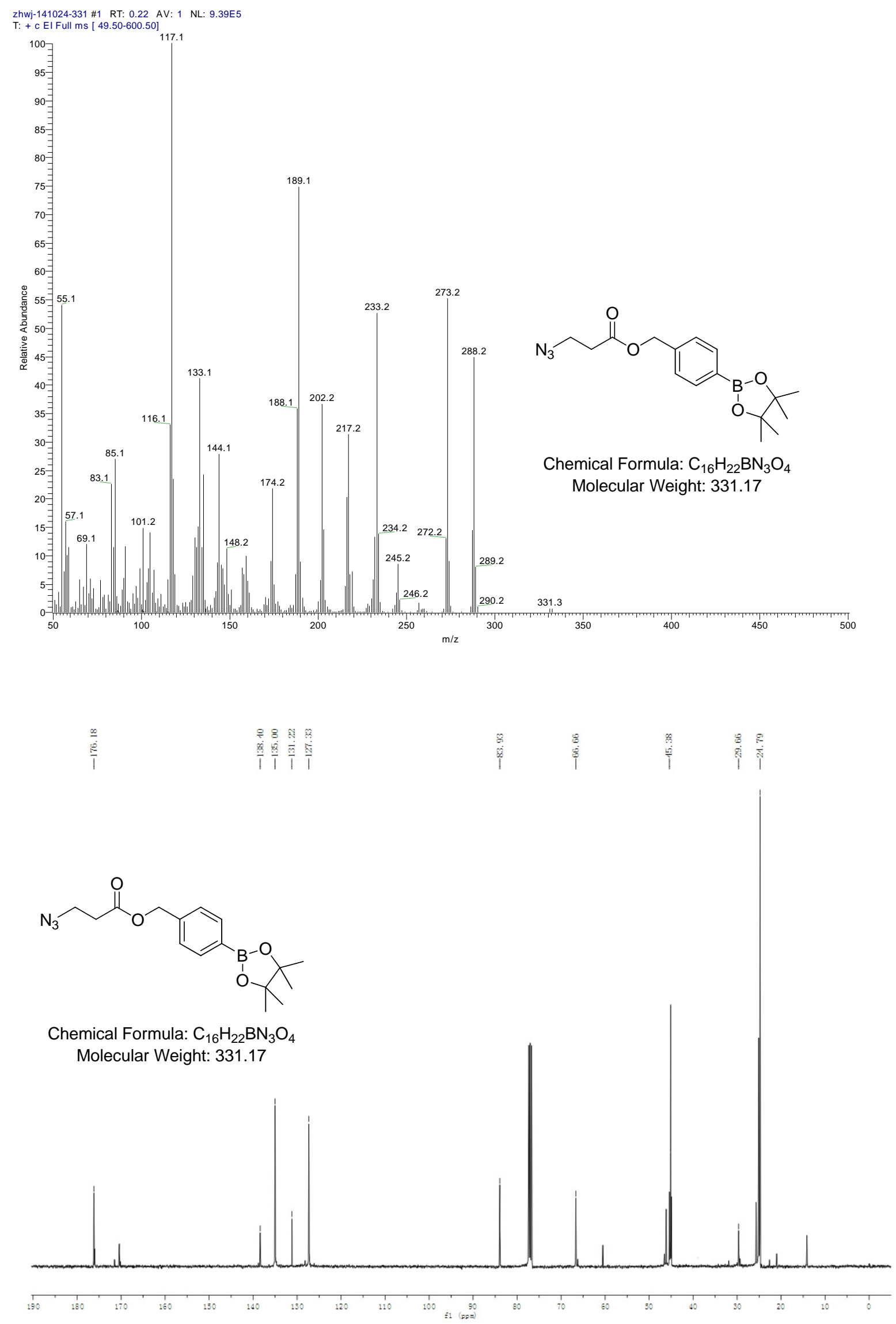

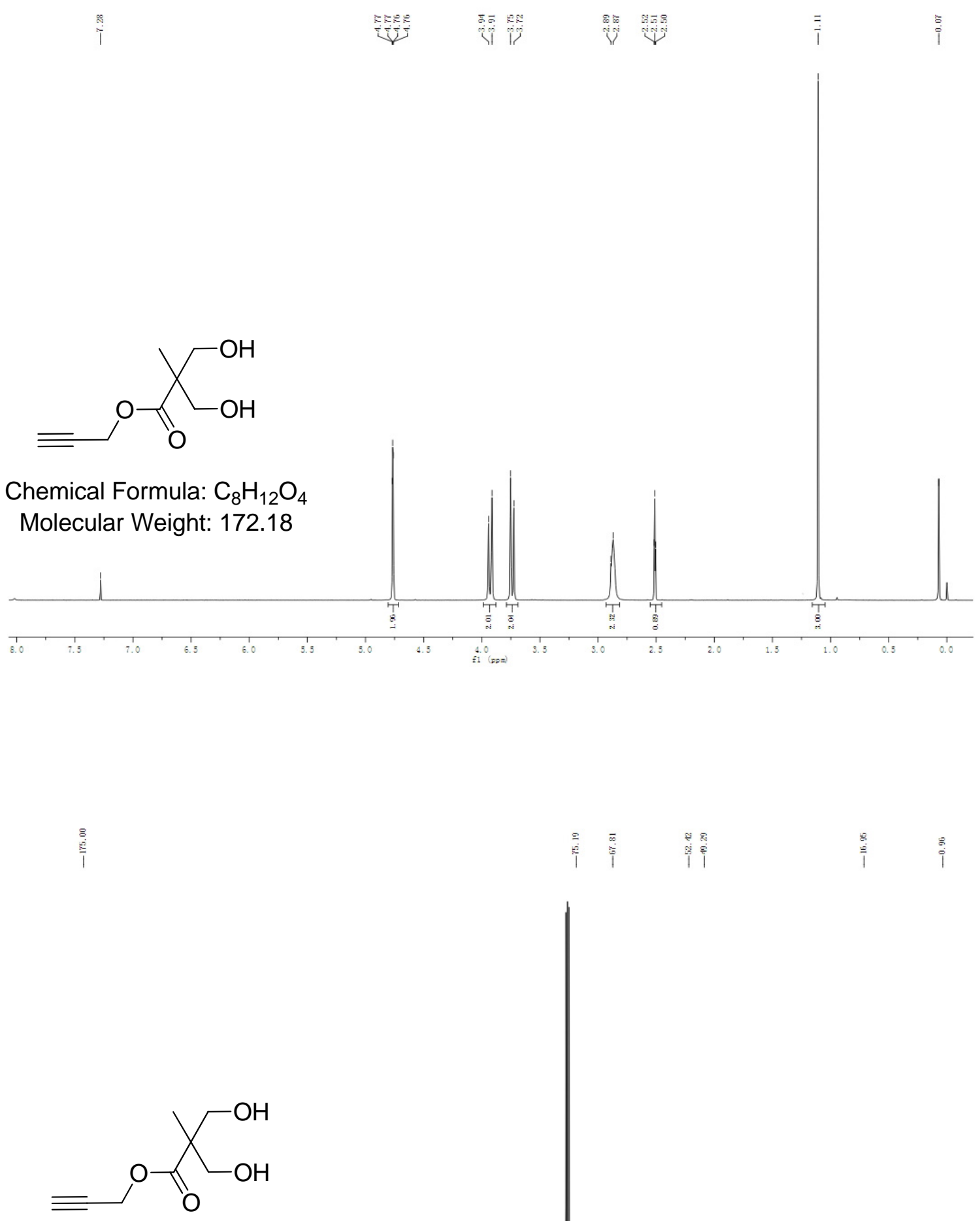

Chemical Formula: $\mathrm{C}_{8} \mathrm{H}_{12} \mathrm{O}_{4}$

Molecular Weight: 172.18 

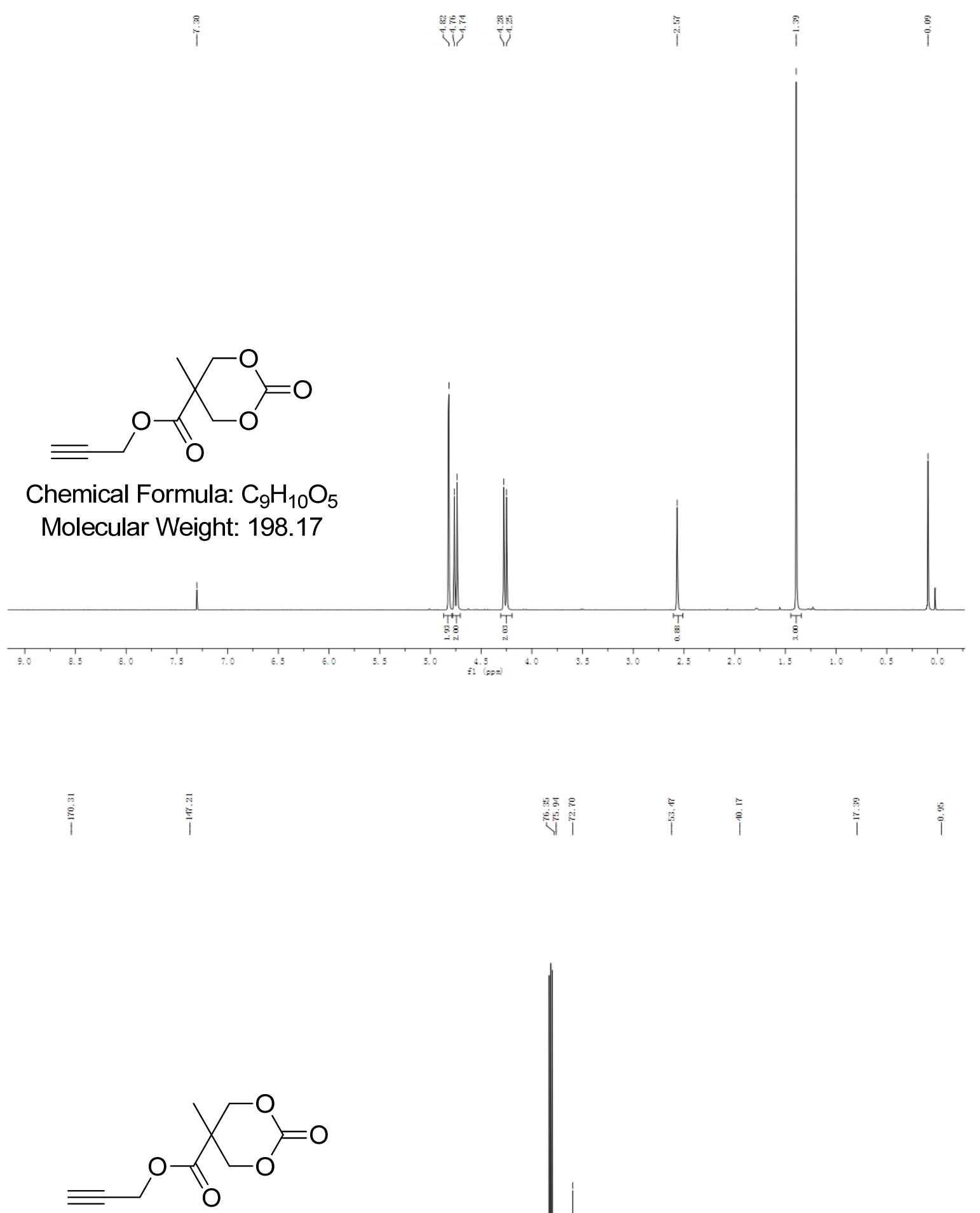

Chemical Formula: $\mathrm{C}_{9} \mathrm{H}_{10} \mathrm{O}_{5}$

Molecular Weight: 198.17
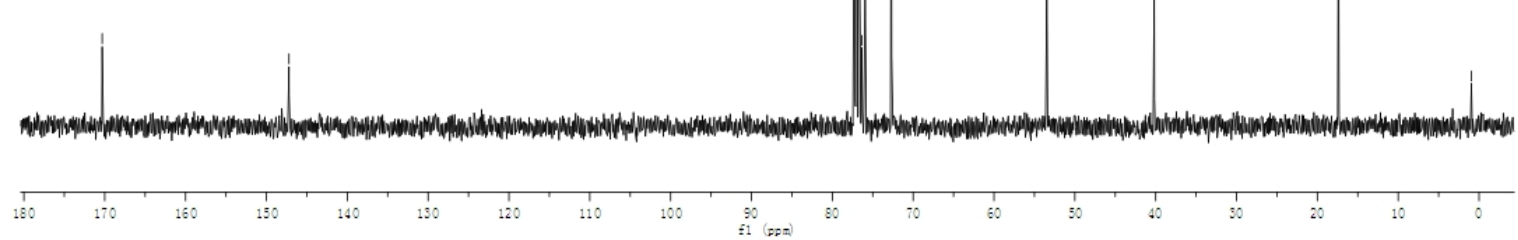


\section{References}

(1) Hagen, H.; Marzenell, P.; Jentzsch, E.; Wenz, F.; Veldwijk, M. R.; Mokhir, Andriy. J. med. Chem. 2012, 55, 924-934.

(2) Yuan, L.; Lin, W.; Zhao, S.; Gao, W.; Chen, B.; He, L; Zhu, S. J. Am. Chem. Soc. 2012, $134,13510-13523$.

(3) Pratt, R. C.; Lohmeijer, B. G. G.; Long, D. A.; Lundberg, P. N. P.; Dove, A. P.; Li, H.;

Wade, C. G.; Waymouth, R. M.; Hedrick, J. L. Macromolecules, 2006, 39, 7863-7871. 